\title{
APPLICATION OF SATELLITE REMOTE SENSING DATA AND GIS ON ENVIRONMENTAL IMBALANCE CAUSED BY MINING ACTIVITIES IN RAMTEK TAHSIL OF NAGPUR DISTRICT.
}

\section{JYOTI RAMTEKE ${ }^{1}$ AND SUNIL RAMTEKE ${ }^{2}$}

${ }^{1}$ Sevadal Mahila Mahavidyalaya Sakkardara Square, Nagpur-440009 (M.S.) INDIA. 2 Junior Geologist, Directorate of Geology and Mining, Govt. of Maharashtra.

E-mail:- ramteke.js99@gmail

ABSTRACT: Remote sensing provides timely, synoptic and repetitive coverage over large areas across various spatial scale, have made it a very powerful tool for monitoring natural resources, like forest, agriculture, irrigation, environmental resources. Remote sensing and GIS, as well as the related technology of digital image processing, global positioning system are used to help, manage and protect the natural resources. Satellite remote sensing has demonstrated its utility in mapping and monitoring of vegetation-cover and changes, analyzing natural resources disturbances apart from other micro-level applications like spatial mapping, its estimation, socioeconomic status, habitat analysis, drinking water, irrigation, agriculture, waste management, drainage pattern, road and railway network, facility and utility management, mapping of geology and mineral reserves with impact on environment. The multisensor approach has proved its capability to identify the source of pollution, accurately determine the location extent and type. GIS is a powerful tool for effective and efficient storage and manipulation of remotely sensed data and other spatial data and non-spatial data for scientific and commercial management and policy-oriented purposes. The present paper shows the capability of mapping of mineral reserves and geology using Satellite Remote-Sensing data, monitoring impact of mining activities on the surrounding environment of Ramtek Tahsil.

Keywords: Environmental Imbalance, Remote Sensing, GIS, and Multi-sensor.

\section{INTRODUCTION:}

"Remote sensing can also be defined as the collection of data about an object from a distance”

"Remote sensing means the observation of a target using a device located some distance away from it." 
Remote sensing is the science and art of acquiring information about the earth surface without actually being in contact with the earth surface. This is done by sensing and recording reflected or emitted energy and processing, analyzing and applying that information. Aerial Photography, Aircraft, Satellites are the most common platform for remote sensing observations and collecting information about the earth's surface.

The geographical information system includes storage of data of various parameters of the object. This data is internally related to each other in the system with different parameter, object on the basis of some common fields such as, field dither relation based database. It helps the user to get the solution in the form of data output to the problem and forward by the user in the form of queries to the information system with respect to the given terms and condition in the queries. The GIS provides the user with set of tools for retrieval, transformation and analysis of both spatial and non-spatial data, which provide an environment, to manipulate and manage location and thematic data. Different objects return different amount and kind of energy in different bands of the electromagnetic spectrum incident upon it. This property of the object depends on structural, physical and chemical composition, surface roughness, angle of incidence, intensity and wavelength of radiant energy. Remote sensing is also a multi-diplomacy science.

Satellite remote sensing related technology, using digital image processing techniques provides very useful accurate, repetitive information for monitoring and management of natural resources. Satellite remote sensing provides useful data to monitor environmental impact on developmental activities of mining and mineral deposites.

The present paper has attempted to identify the Environmental Imbalance caused by mining activities in Ramtek Tahsil of Nagpur district using Remote Sensing and GIS techniques. 


\section{MATERIALS AND METHODS:}

In this study the Mapping of Geological features and Mineral deposits are shown using IRS LISS-III data of Indian remote-sensing satellite. The study highlighted the impact of mining activities in Ramtek Tahsil area. Manganese Ore mine near Kandri village and Mansar village. Some Dolomite mines near Karwahi Village and Patgowari Village of Ramtek Tahsil. Most of the land is converted into Wastelands \& Non vegetative.

Plate I \& Plate II shows the impact on vegetation. Comparison of vegetation can be calculated by change detection techniques using different sets of satellite data with temporal resolution \& classification techniques using digital image processing methodology. Various spectral signatures are studied and variation in spectral bands are noted to find out the disturb area due to mining activities using remote sensing.

The study area taken for the present work is Ramtek tahsil of Nagpur district of the Maharashtra state. Ramtek township is located about $45 \mathrm{Kms}$. From Nagpur city towards NE direction. The total extent of Ramtek taluka is bounded by the latitude and longitude of $79^{\circ} 10^{\prime} 14 \mathrm{E}$ to $21^{043} 3^{\prime} 15 \mathrm{~N}$ and $79^{\circ} 32$ '39 E to $21^{0} 1641 \mathrm{~N}$ the total geographical area of $1162.52 \mathrm{sq} \mathrm{km}$ and the dominant part of Ramtek taluka is covered by forest area. Ramtek is known for the religious place in the history due to Ram temple on the top of hill near Ramtek town. Khindsi dam is also known for picnic spot. 


\section{Location Map Of Ramtek Tahsil}

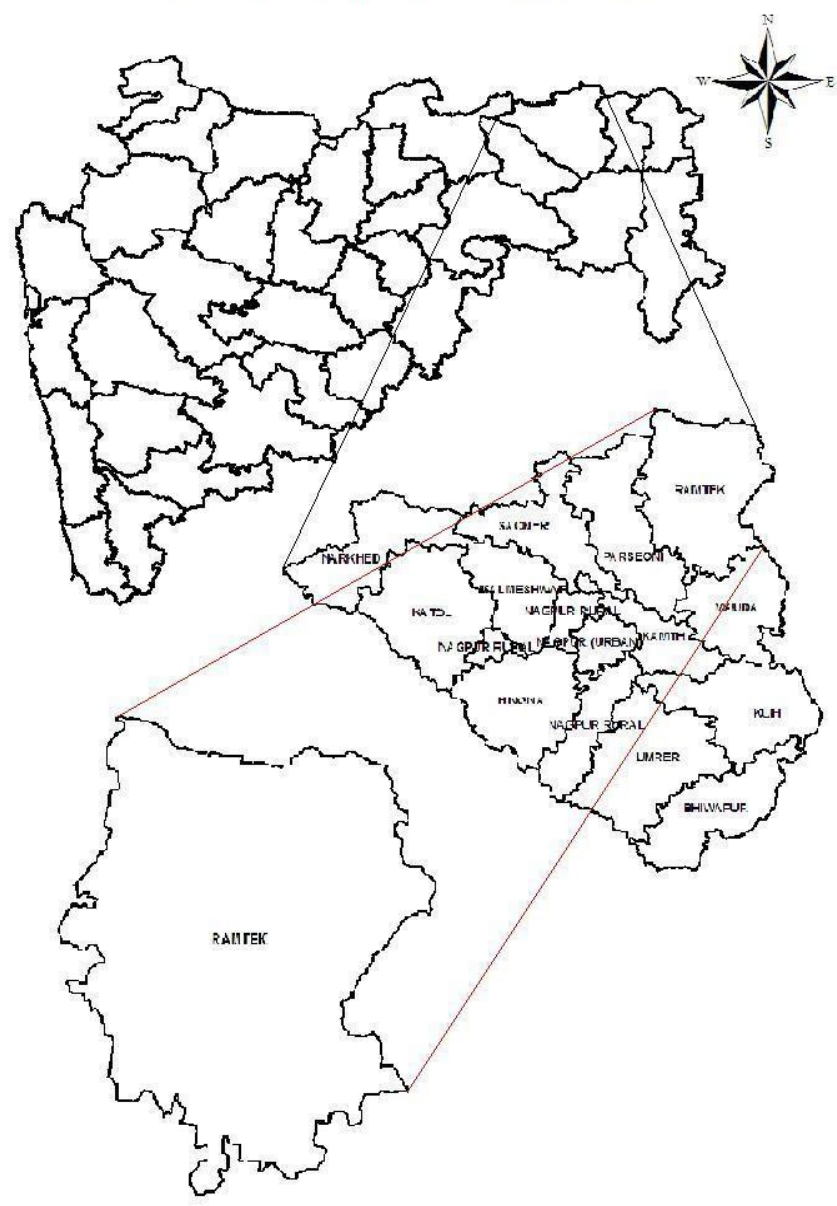

\section{RESULT AND DISCUSSION}

Some of the observations using remote sensing are listed below (Table-1).

The area is having forest and agricultural land. Dense tropical forest vegetation grows due to sufficient rainfall and rich soil. The thick forests offer ideal climate for wild animals and birds. The main flora and fauna reported are as follows:

\section{Flora:}

1) Bija (Pterocarpus marsupium)

2) Babul (Acacia arabica) 
3) Chandan (Santalum album)

4) Dhaora (Anogeissus latitolia)

5) Salai (Boswelllia serrata)

6) Sagwan-Teak (Tectona grandis)

\section{Fauna:}

1) Bagh Tiger (Panthera Tigris)

2) Bhaisa Jungali (Bubalus bubalis)

3) Chital (Axis axis)

\section{Geology of Ramtek Tahsil:}

Stratigraphic sequence of formations in Ramtek Tahsil Area.

Bichua Fm.- Crystalline Limestone, Dolomite.

Junewani Fm. - Muscovite- biotite schist, quartz biotite and granulite.

Chorbaoli Fm.- Quartzite and Quartz Mica Schist

Mansar Fm.- Muscovite biotite schist with Manganese Ore

Lohangi Fm. - Calc- gneiss and Manganiferous Marble with Manganese Ore

Sitasaongi Fm.- Quartz- Mica schist, feldspar- Mica schist and Intercalated Quartzite.

$$
\text { -- unconformity -- }
$$

TBG Fm. - Tirodi Biotite Gneiss

Rock formation in Ramtek Tahsil area ranging in age from Sausar to Sakoli formation is exposed. Tirodi Gneissic complex of Archaean to Palaeo Proterozoic age (>2500-2300 m.y.) comprising migmatite, orthogeneiss and granulite occupies the eastern and northeastern part. An outcrop of granulite is marked at $14 \mathrm{~km}$. North-east of Mauda. Sausar group of mesoproterozoic 
occupies the Ramtek Tahsil area and comprises quartz muscovite schist. Feldspar muscovite schist and intercalated quartzite (Sitasawangi formation). Calc-Gneiss and manganiferous marble with pocket of manganese ore (Lohangi formation).

Muscovite biotite schist with manganese ore (Mansar formation). Quartzite and quartz muscovite schist (Chorbaoli formation) Muscovite biotite schist and quartzite granite (Junewani formation) and crystalline limestone formation and dolomite (Bichua formation), which are repeatedly tight and folded. The Sausar group is a storehouse of manganese ore deposits.

\section{Mines:}

a) Karwahi area:- Number of mines for dolomite minerals are situated around the Karwahi village area.

b) Patgowari Mine: Dolomite Mine near Pategowari village is presently under the possession of Maharashtra State Mining Corporation.

c) Gidaljhori area: The boulders and lenses of manganese bearing rocks have been worked out. Mine site is $1 \mathrm{~km}$. north-east to Gidaljhori village.

d) Belda: $21^{035}$ ' : $79^{\circ} 27^{\prime}$ :- The old pit is situated $1 \mathrm{~km}$. west of Belda and $2 \mathrm{kms}$ south of Navegaon, in the forest. The manganese bearing Gondite is exposed in the pit at a depth of $6 \mathrm{~m}$.

e) Pusada-Tangla (21032': 79033' and 21032', 79029'30"):- The PusadaTangla Forest road from Pindkepar is characterized by exposures of calc.g granulites and granite forming isolated hillooks. Thin band of Gondite is exposed in quartz mica schist striking NW-SE with $40^{\circ} \mathrm{SW}$ dip. The lenses and loose boulders of manganese bearing Gondite are present. 


\section{Geological structure of Ramtek Tahsil}

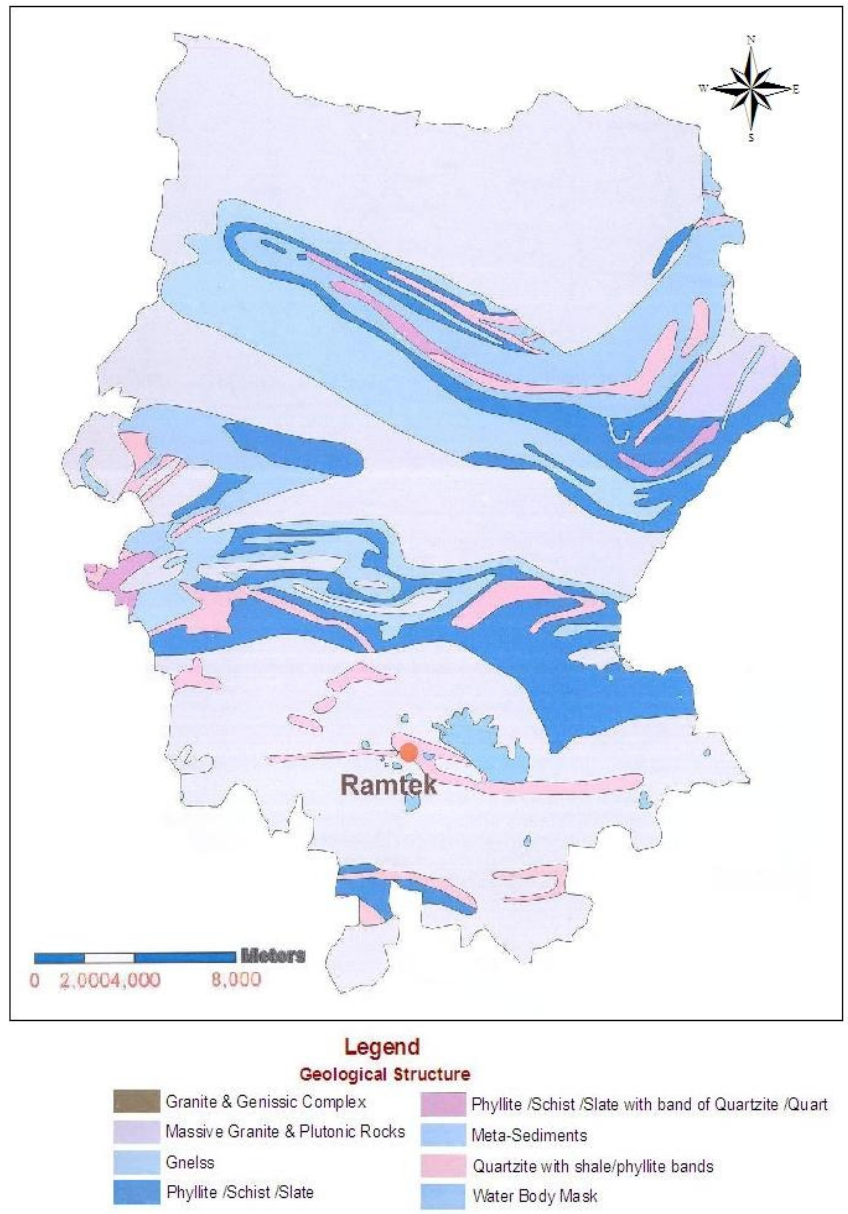

\section{Impact of mining on surrounding areas:}

1. Ground vibration: Blasting operations in mining areas generally causes ground vibrations. Due to this the houses in nearby villages get damaged with cracked walls. It is very difficult for the villagers to repair their houses. Even sometime Railways and roads also can get damaged.

2. Air pollution: Air pollution is caused due to fines, dust, mining, beneficiation or metallurgical operations. Also smoke, gaseous emission from mining industries causes air pollution. 
3. Noise Pollution: Noise arising out by mineral transportation, mining, beneficiation or metallurgical operations.

4. Restoration of Flora: Mining activities causes some or other damages to the flora of the nearby areas.

\section{Remedies:}

As per government norms blasting operations in mining areas should be within safe limits from residential area and compensation should be provided to the villagers for the damages of their houses. Scientific Investigations should be carried out by the mine owners so as to keep the ground vibrations caused by blasting operation within safe limit.

Air pollution should be controlled and kept within permissible limits specified under various environmental laws. Trees should be planted around colony, roads, over burden dumps and industrial areas. Noise pollution should be controlled and kept it within permissible limit. Green barrier, well designed silencers and mufflers around mining area should be made compulsory.

Flora should be restored and planted in the same area, planting should not be less than twice the number of trees destroyed due to mining activities. Due to these norms of government most of the areas are in controlled when monitored using remote sensing. Most of the area when converted into quarries and pits later it should be converted into fishponds and other farming methods.

\section{CONCLUSION:}

The present study concludes with the use of GIS and Remote Sensing Satellite Images for providing accurate data of disturbed area caused by mining activities for monitoring and management of natural resources. Land use land cover study using remote sensing and GIS indicated the area in different 
classes listed herewith. Due to impact of mining activities there is possibility of land inuse can get converted into wastelands as indicated in table - I.

Table 1: Land Use / Land Cover Classes in Ramtek Taluka, Nagpur District.

\begin{tabular}{|c|c|c|c|}
\hline $\begin{array}{l}\text { LEVEL I } \\
\text { Classification }\end{array}$ & $\begin{array}{l}\text { LEVEL II } \\
\text { Classification }\end{array}$ & $\begin{array}{l}\text { LEVEL III } \\
\text { Classification }\end{array}$ & $\begin{array}{l}\text { AREA ( } \\
\text { Sq.KM.) }\end{array}$ \\
\hline Agriculture & Fallow & Current Fallow & 0.173 \\
\hline Agriculture & Plantations & Horticulture & 0.321 \\
\hline Agriculture & Crop land & Kharif & 813.262 \\
\hline Agriculture & Crop land & Kharif + Rabi & 87.405 \\
\hline Agriculture & Crop land & Rabi & 21.323 \\
\hline & Towns/Cities & & \\
\hline BUILT-UP & (Urban) & Residential & 1.733 \\
\hline BUILT-UP & Villages (Rural) & Villages (Rural) & 4.534 \\
\hline Forest & $\begin{array}{l}\text { Deciduous } \\
\text { (Moist/Dry) }\end{array}$ & Dense/Closed & 840.603 \\
\hline Forest & $\begin{array}{l}\text { Deciduous } \\
\text { (Moist/Dry) }\end{array}$ & Open & 48.036 \\
\hline Forest & $\begin{array}{l}\text { Deciduous } \\
\text { (Moist/Dry) }\end{array}$ & Scrub Forest & 2.904 \\
\hline Wastelands & Land with scrub & Land with scrub & 130.829 \\
\hline Wastelands & Land without & Land without & 9.055 \\
\hline
\end{tabular}


International Journal of Researches in Biosciences, Agriculture \& Technology

September 2013

Issue-1, Volume-1

ISSN No. (Online):

2347-517X

\begin{tabular}{|l|l|l|l|}
\hline Wastelands & $\begin{array}{l}\text { Mcrub } \\
\text { waste }\end{array}$ & scrub & \\
\hline Water bodies & Reservoirs & Reservoirs & $\mathbf{0 . 6 0 8}$ \\
\hline Water bodies & River & River & 50.189 \\
\hline Water bodies & Tanks & Tanks & 93.370 \\
\hline & & Total Area & 12.015 \\
\hline
\end{tabular}

Disturbance/Impact on Land cover \& Land use Due to Mining Activities

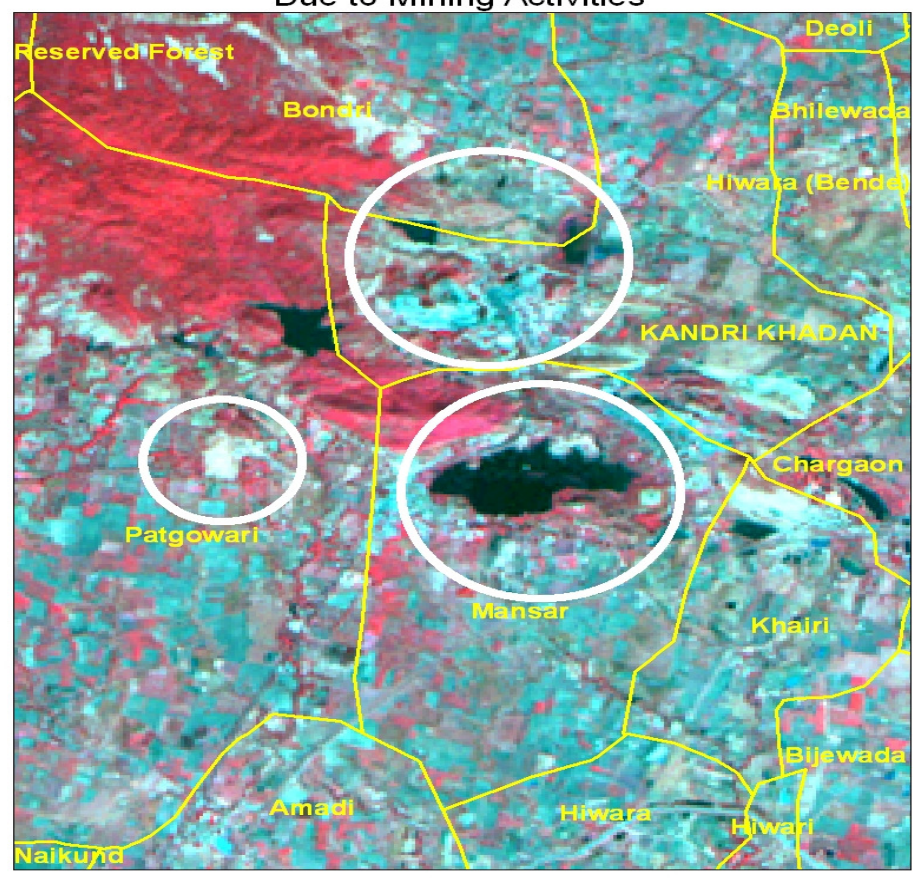

\section{Plate I}


Disturbance/Impact on Land cover \& Land use Due to Mining Activities

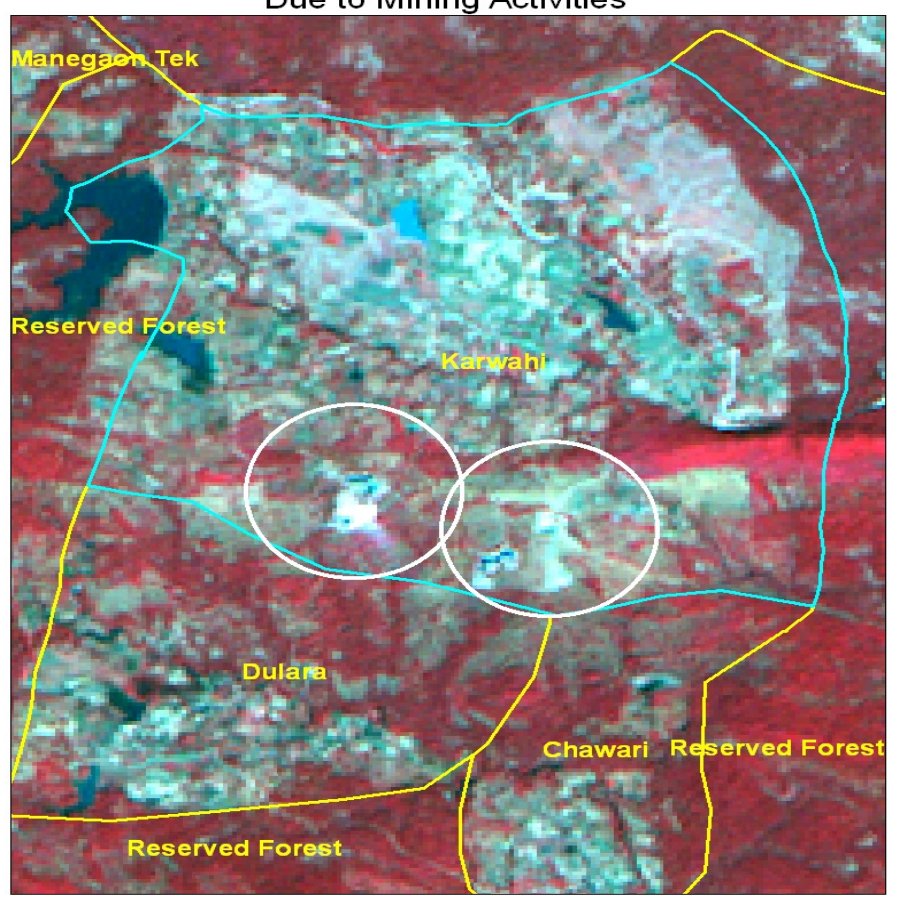

\section{Plate II}

\section{ACKNOWLEDGEMENTS :}

The authors are grateful to Mr. V. S. Savakhande, Director of Geology Mining, Govt. of Maharashtra, Nagpur, for providing the book, "Geology and Mineral Resources of Maharashtra 2000", Dr. S. V. Balamwar, Associate Scientist, MRSAC, Nagpur and Mr. Ashok Metpalliwar, Scientific Associate, MRSAC, Nagpur for their kind guidance, cooperation and encouragement during the course of this paper. 


\section{REFERENCES:}

Abrams, M. J.; R. Ashley; L. Rowan; A. Goetz y A. Kahle. 1977. Mapping of hydrothermal alteration in the Cuprite Mining District, Nevada, using aircraft scanner images for the spectral region 0.46 to $2.36 \mathrm{um}$. Geology 5: 713-718.

Bauer, R. 2006. Mine Subsidence in Illinois: Facts for homeowners. Illinois department of Natural Resources. Circular 569, 30 pp.

Buckingham, W. F. y S. E. Sommer. 1983. Mineralogical characterization of rock surfaces formed by hydrothermal alteration and weathering. Application to Remote Sensing. Economic Geology 78:664-674.

Chica, M. and F. Abarca. 2002. Development of a decision Support System based on remote sensing and GIS techniques for gold-rich area identification in SE Spain. International Journal of Remote Sensing. Vol. 23 (22):4801-4814.

A. Bhattacharya, 2000. "Remote Sensing Applications for Geology and Geomorphology: Retrospective and Perspective". Seminar at Regional Remote Sensing Service Centre, Department of Space, Government of India, Nagpur.

Geology and Mineral Resources of Maharashtra, 2000 by Directorate of Geology and Mining, Govt. of Maharashtra, Nagpur.

Green, K., Kempka, D. and Lackley, L. 1994. Using remote sensing to detect and monitor land cover and land use changes. Photogra. Eng. Remote Sensing. 60(3):331-337.

Kam, T.S. 1995. Integrating GIS and remote sensing techniques for urban land-cover land-use analysis. Geoc. Int., 10(1):39-49.

King, R.B. 2002. Land cover mapping principles: a return to interpretation fundamentals. Int. J. Remote Sensing, 23(18):3523-3545. 